\title{
脱気塩酸中の高純度 $\mathrm{Al}$ の腐食とアクリジン添加の影響*
}

\author{
小林 賢三**, 清水 健一**, 大矢 徹***, 大羽 通安**** \\ $* *$ 慶應義塾大学理工学部 \\ ***慶應義塾大学経済学部 \\ **** (現) 関東医師製薬 (株)
}

\section{Corrosion Behaviour of High Purity Aluminium in Deaerated Hydrochloric Acid with and without Acridine*}

\author{
Kenzo Kobayashi**, Kenichi Shimizu**, Toru Ohya*** and Michiyasu Ohba**** \\ **Faculty of science and technology, Keio University \\ ***Faculty of economics, Keio University \\ ****Kanto Ishi Seiyaku Co. Ltd.
}

\begin{abstract}
Corrosion behaviour of $99.99 \%$ aluminium was studied in deaerated $2 \mathrm{~N}$ hydrochloric acid aqueous solution with and without acridine by potentiostatic polarisation measurements and surface observation with scanning electron microscopy (SEM). The polarisation curves of the aluminium gave Tafel's relationship in the range of cathodic and anodic potentials between -1100 and -1380 , and between -980 and $-860 \mathrm{mV}$ vs. SCE, respectively in the acid without acridine. The current density was found to increase suddenly at cathodic potentials below -1400 , and at anodic potentials above $-860 \mathrm{mV}$ vs. SCE, respectively. Acridine added in the acid showed to inhibit the anodic reaction, but to accelerate the cathodic reaction, owing to the hydrogenation of acridine. The potentials where the current density increased abruptly were not affected by acridine added. After the specimens were polarised below -1400 , or above $-840 \mathrm{mV}$ vs. SCE in the acid without acridine, SEM observation of the surface has shown numerous small crystallographic pits of sizes up to few $\mu \mathrm{m}$ with occasional appearance of developed pits of sizes, several tens $\mu \mathrm{m}$. It is concluded that the aluminium has been covered with oxide layer, probably amorphous air-formed one, in hydrochloric acid aqueous solution similar to that in neutral aqueous solution containing $\mathrm{Cl}^{-}$ion and is corroded through it, and acridine inhibits strongly the formation of small pits on the surface polarised below -1400 , and above $-840 \mathrm{mV}$ vs. SCE.
\end{abstract}

\section{1. 緒言}

アルミニウムは非常に酸化され易い金属で，大気中で も容易に酸化皮膜が形成され，その酸化皮膜は電気化学 的に簡単には還元されないと一般に言われている。イン ヒビターを用いたアルミニウムの酸腐食に関する論文 は, 往々にしてアルミニウム上の酸化皮膜の存在が考慮 されず,アルミニウムは酸中であたかも活性溶解が起こ

* 日本化学会, 第 21 回化学関連支部合同九州大 会で一部発表

** 于223 横浜市港北区日吉 3-14-1 (3-14-1 Hiyoshi, Kohoku-ku, Yokohama-shi, 223 Japan).

*** ₹223 横浜市港北区日吉 4-1-1 (4-1-1 Hiyoshi, Kohoku-ku, Yokohama-shi, 223 Japan).
り，そしてインヒビターが裸のアルミニウム表面に吸着 するように受止められる記述が多いと思われる。しかし ながら，アルミニウムを強酸中に浸漬したとき，その浸 漬電位はアルミニウムの酸化還元電位より貴な值を示す のが一般である。このことは強酸中に朔いても，アルミ 二ウムの酸化皮膜は完全に溶解し去るのでなく，その皮 膜を通して起こっているように思われる。

そこで，脱気 $2 \mathrm{~N} \mathrm{HCl}$ 水溶液中に打活る $99.99 \%$ ア ルミニウムの腐食を定電位分極法, 及び走査型電子顕微 鏡観察を行い，また塩酸中にインヒビターとしてアクリ ジンを添加した場合の結果との比較から，アルミニウム の塩酸中に和ける腐食反応について報告する。 


\section{2. 実験方法}

試験片として $99.99 \%$ アルミニウム $(40 \times 10 \times 0.3$ $\mathrm{mm}$ ) を用いた。試験片はアルミニウムのリード線を付 し, 電極表面, 約 $1 \mathrm{~cm}^{2}$ を残し, エナィル塗装した。塗 膜が十分飞乾燥した後, 過塩素酸ーエタノール溶液中で 電解研磨を行い, 次いで $1 \mathrm{~N} \mathrm{NaOH}$ 水溶液中に 2 分間 浸漬, 蒸留水で十分に洗浄後, 直ちに実験に供した。

定電位分極曲線の測定はH型セル中で，電位を飽和カ ロスル電極に照合し，対極に白金網を用い，自然浸漬条 件下に 1 時間保持したのち, 自然浸漬電位からカソード 方向, あるいはアノード方向に $20 \mathrm{mV}$ 間隔で電位を移 行して行った。腐食後の $2 \mathrm{~N} \mathrm{HCl}$ は特級濃塩酸と再蒸 留水から調製し, 沜とら処理敊よび $\mathrm{N}_{2}$ ガス通気により 脱颌した。またイインヒビターとして用いたアクリジン は特級試薬を再結晶法により精製したものを用いた。

\section{3. 実験結果及び考察}

脱気した $30^{\circ} \mathrm{C}, 2 \mathrm{~N} \mathrm{HCl}$ 中の $99.99 \% \mathrm{Al}$ の分㯙曲 線, 及び去の $\mathrm{HCl}$ 中にアクリジンを $5.0 \times 10^{-4}$ から $1.0 \times 10^{-2} \mathrm{M}$ までの種ぬの濃度で添加し, $\mathrm{A} 1$ の分極曲 線に及添す影響を調べた。その結果をFig. 1 亿示した。 眖领した $2 \mathrm{~N} \mathrm{HCl}$ 水溶液中に郝子る $99.99 \% \mathrm{Al}$ の自 然浸漬電位は約 $-1080 \mathrm{mV}$ vs. SCE であり, カソード 側 -1100 から $-1380 \mathrm{mV}$ vs. SCE をでの電位範用, 及びアノード側 -980 から $-860 \mathrm{mV}$ vs. SCE までの 電位籁囲において，それぞれ Tafel 領域が認められた。 しかし，電位がカンード側 $-1400 \mathrm{mV}$ vs. SCE 及びア ノード側 $-840 \mathrm{mV}$ vs. SCE 付近に達すると電流の急

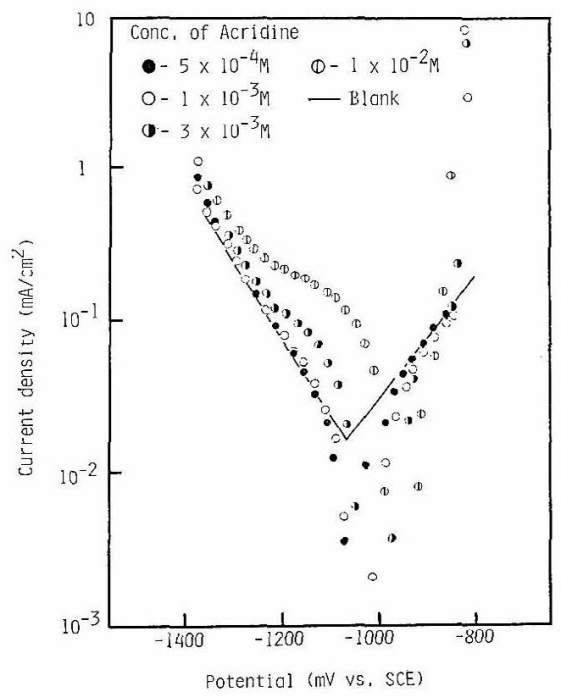

Fig. 1 Polarisation curves of $99.99 \%$ aluminium in $2 \mathrm{~N} \mathrm{HCl}$ aqueous solution with and without acridine at $30^{\circ} \mathrm{C}$.

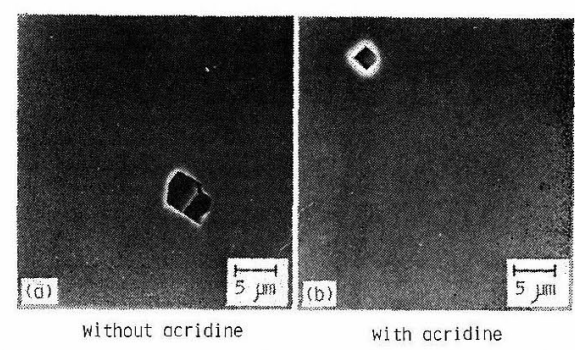

Fig. 2 Scanning electron micrographs of the aluminium surface after polarisation in the range of the potentials between -1380 and $-860 \mathrm{mV}$ vs. SCE in $2 \mathrm{~N} \mathrm{HCl}$ aq. solution without acridine (a), and with $3 \times 10^{-3} \mathrm{M}$ acridine (b), at $30^{\circ} \mathrm{C}$.

激な増加が起こった。

分極湘定後, 試料表面を走査型電子影微鏡 (SEM) 観 察の結果, Tafel 領域を示したー1380 から $-860 \mathrm{mV}$ vs. SCE の範囲に扮いては, 試料表面ね Fig. 2 (a) 飞示 したように平滑であり，数は少ないが，1 N NaOH に 浸潰した時に生じたと推定される数 $\mu \mathrm{m}$ 程度の大きさの ピットが観察されるのみで, 電位による表面状態の差異 は殆ど認められなかった。これ対して, 電流が急激に 立上がる $-1400 \mathrm{mV}$ vs. SCE 上り卑, 西るいは -840 $\mathrm{mV}$ vs. SCE より貴な電位まで分極した後の試料表面 には，結晶方位に依存した形態をもつピットの発生が認 められた。それらのSEM 観察の結果をそれぞれ Fig. 3 (a) 及び (b) K示した。双方共表面には数十 $\mu \mathrm{m}$ 程度 までの大きさをるつ無数のピットに加え, 数十 $\mu \mathrm{m}$ 程度 の大きさまで発達したピットす存在していることがわか る。

$-1400 \mathrm{mV}$ vs. SCE より卑, 及び $-840 \mathrm{mV}$ vs. SCE より貴の電位においてピットの発生が認められた事実は 次のように説明される。アノード側で電流の急激な増 加, 及びピットの発生が認められたアノード電位 $(-840$ $\mathrm{mV}$ vs. SCE) は $\mathrm{Cl}^{-}$イオンを含む中性水溶液中に打 ける高純度 $\mathrm{A} 1$ の孔食電位に汪济対応するりことから， 脱気した $2 \mathrm{~N} \mathrm{HCl}$ 水溶液中に和いても $\mathrm{A} 1$ 表面には酸 化皮膜が存在していると推定される。この酸化皮膜は自 然空気酸化皮膜に類似した無定形了ルミナ皮膜と考无る のが妥当であろう。

酸化皮膜の生成反応, 及びそれに対する平衡電位 $\left(E_{0}\right)$ は先れぞれ次式で与えられることが知られている2》。

$$
\begin{gathered}
2 \mathrm{Al}+3 \mathrm{H}_{2} \mathrm{O}=\mathrm{Al}_{2} \mathrm{O}_{3}+6 \mathrm{H}^{+}+6 \mathrm{e} \\
E_{0}=-1.494-0.059 \mathrm{pH}
\end{gathered}
$$

(2) 式の平衡電位は生成自由エネルギーが各種アルミ ナの中で唯一既知な $\alpha$-アルミナに対して計算された值で あり，無定形アルミナに直接対応するものではない。し かし，無定形アルミナと $\alpha$ アルミナ生成に対する自由エ 


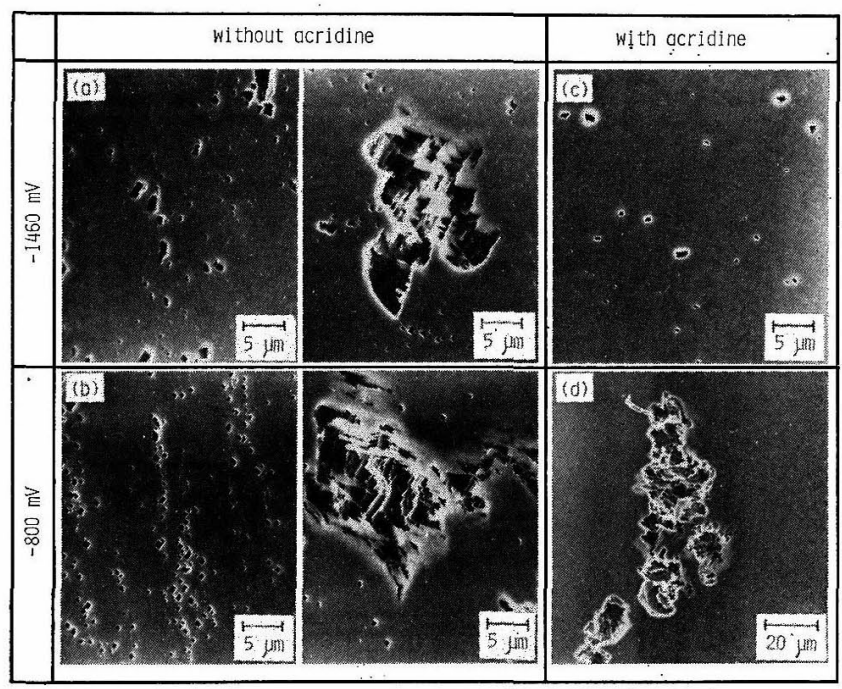

Fig. 3 Scanning electron micrographs of the aluminium surface after polarisation in $2 \mathrm{~N} \mathrm{HCl}$ aq. solution with and without acridine at $30^{\circ} \mathrm{C}$.

Conc. of acridine

$$
3 \times 10^{-3} \mathrm{M}
$$

$-1460 \mathrm{mV}$ vs. SCE

(a)

(c)
$-800 \mathrm{mV}$ vs. SCE

(b)

(d)
ネルギーの差がそれ程大きくないと仮定すれば，酸化皮 膜生成に対する平衡電位から，脱気した $2 \mathrm{~N} \mathrm{HCl}$ 水溶 液中に浸漬された $\mathrm{A} 1$ 表面に酸化皮膜が存在すると考光 るのは，少なくとも熱力学的には不合理ではない。した がって，A1 表面に酸化皮膜加存在すると考光れば， - $1400 \mathrm{mV}$ vs. SCE より卑な電位における ピットの発 生は， $\mathrm{Al}$ 表面を覆っている酸化皮膜が，その電位で局 部的に不安定となり，その結果，皮膜が局部的に失われ 活性な $\mathrm{Al}$ 素地が露出した筒所では皮膜で覆われた部分 と比較し, 活性な $\mathrm{A} 1$ の溶解, 及び水素発生が起きると 考觉れば説明できる。また， $-840 \mathrm{mV}$ Vs. SCE より貴 な電位でのピットの発生は $\mathrm{Cl}^{-}$イオンを含む中性水溶液 中でのピットの発生と同㴍，アルミニウム酸化皮膜への $\mathrm{Cl}^{-}$イオンの吸着, 次いで $\mathrm{Cl}^{-}$イオン皮膜中への浸入 により ${ }^{3)}$ ，また酸化皮膜の欠陥部 ${ }^{4)}$ より起こると推定さ れる。

脱気 $2 \mathrm{~N} \mathrm{HCl}$ 水溶液 $\left(30^{\circ} \mathrm{C}\right)$ 中にアクリジンを添加 すると, $99.99 \% \mathrm{Al}$ の自然浸漬電位はアクリジンの添 加濃度を増すに従い, $-1050 \mathrm{mV}$ vs. SCE から -980 $\mathrm{mV}$ へと徐々飞貴な方向にシフト-5る。また, Fig. 1 に 示したように, アクリジン存在下では A1 のカソード反 応が促進され，アノード反応は抑制されることがわか る。カソード反応の促㕠, 及びアノード反応の抑制はア クリジン添加濃度が高い程大きい。電位が $-1400 \mathrm{mV}$ vs. SCE，あるいは $-840 \mathrm{mV}$ vs. SCE に達すると，ア クリジン存在下に打いてもアクリジン無添加時と同様,
電流の急激な増加が認められた。種々の電位なで分極し た試料表面の SEM の観察結果を,アクリジン添加濃度 が $3.0 \times 10^{-3} \mathrm{M}$ の場合を例として Fig. 3 に示した。 -1380 から $-860 \mathrm{mV}$ vs. SCE の電位範囲に打いて は，分極後の試料表面は Fig. 2 (b) に示したように平 滑であり, アクリジン無添加時と同様, 時々数 $\mu \mathrm{m}$ 程度 の大ささのピットが観察されるのみで, 電位による表面 状態の差異は殆ど認められなかった。しかし, -1400 $\mathrm{mV}$ vs. SCE より卑, あるいは $-840 \mathrm{mV}$ vs. SCE よ り貴な電位まで分極した後，試料表面には，それぞれ Fig. 3 (c) 及び (d) に示したよらにピットの発生が認め られた。アクリジン無添加恃のそれと比較すると, 発生 するピットの密度がアノード側，カソード側双方に特い て著しく低いことがわかる。この傾向はアタリジン濃度 が高い程著しく，爽たカソード側よりアノード側におい て特に顕著であった。アクリジン存在下に抦いて -800 $\mathrm{mV}$ vs.SCE まで分極した後の試料表面には，アクリジ ン無添加時に括いて同一電位まで分極した後の試料表面 に存在した数 $\mu \mathrm{m}$ 程度までの大きさの無数のピットは全 く存在せず，数十 $\mu \mathrm{m}$ 程度の大ささに発達したピットが 所々に観察されるのみである。すなわり，アクリジンは 小さなピットの発生を抑制し, その作用はカソード側上 りアノード側に招いて特に著しいことがわかる。

著者らは前報 ${ }^{5}$ において, 脱気した塩酸中にお汓る $\mathrm{Al}$ の腐食に対するアクリジンの防食作用は, Al 表面への アクリジン及びアクリジニウムイオンの吸着, 次いでア 
クリジンの還元生成物である塩酸水溶液に難溶なアクダ ンと 9,9'-ビアクリダンが Al 表面に凝集した皮膜を形 成するためであることを示した。本研究では，アクリジ ンは A1 のアノード反応を抑制し, ピットの発生を強く 抑制することが判明した。この結果はアクリジン及び還 元生成物であるアクリダンと $9,9^{\prime}-$ ビアクリダンが $\mathrm{Al}$ 表 面の酸化皮膜を保護し，ピットの発生と酸化皮膜を通し ての Al の溶解反応を抑制すると考えれば容易に説明で きる。アクリダン及び 9,9'-ビアクリダンよりなる皮膜 が $\mathrm{Al}$ 表面に形成されれば，水素発生反応子抑制される と期待されるが, 分極曲線の測定結果は, 逆にアクリジン 存在下では Al のカソード反応が促進されることを示し ている。アノード分極時とは異なり, カソード分極時に は $\mathrm{A} 1$ 表面で水素発生が起こる。この時併行して形成さ れるアクリジンの還元生成物であるアクリダンと $9,9^{\prime}-$ ビアクリダンは水素発生のため, A1 表面に止り凝集し て皮膜を形成することができず，沖合へと拡散してしま うものと考えられる。したがって，カソード分極時には A1 表面にアクリダンと 9,9'-ビアクリダンよりなる皮膜 が形成されず，水素発生反応と併行して起こるアクリジ ンの還元反応の寄与分だけカソード反応は，アクリジン 無添加時と比べ増加する結果となったと考㝋られる。

\section{4. 結 論}

脱気した $2 \mathrm{~N} \mathrm{HCl}$ 水溶液中の $99.99 \% \mathrm{~A} 1$ の定電位 分極曲線及び種々の電位まで分極後の試料表面の走査型 電子顕微鏡観察の結果から次のような結論を得た。
1. 脱気した $2 \mathrm{~N} \mathrm{HCl}$ 水溶液中に括いて腐食してい る $\mathrm{Al}$ 表面は酸化皮膜で覆われて拈り，その皮膜を通し て溶解反応が起こる。

2. 塩酸中に打いて, アノード側 $-840 \mathrm{mV}$ vs. SCE, カソード側 $-1400 \mathrm{mV}$ vs. SCE 付近に孔食電位が認め られた。

3. 塩酸中に添加したアクリジンは, その吸着のため アノード反応を抑制するが，吸着したアクリジンが Al 表面で還元されるため, カソード反応が促進された。

4. アクリジンは $\mathrm{Al}$ 表面のピット発生を抑制する。 その作用はカソード側よりアノード側で強く認められ た。

\section{謝辞}

本研究の一部は, 慶応義塾学事振興資金によって行わ れた。記して謝意を表する。

(Received October 22, 1984)

\section{文献}

1) 当摩 建, 竹内 庸: 軽金属, 29, 232 (1979).

2) M. Pourbaix, N. de Zoubov \& J. van Muylder: Atlas D'equilibres Électrochimiques, p. 169 , Gauthier-Villars, Paris, (1963).

3) M. A. Heine, D. S. Keir \& M. J. Pryor: $J$. Electrochem. Soc., 112, 29 (1965).

4) J. A. Richardson \& G. C. Wood: Corros. Sci. 10, 313 (1970).

5）小林賢三，清水健一，大矢 徹：防食技術， 34, 389 (1985)。 